\title{
Using Brain Science Theory to Analyze the Unity between Language Input and Output: Methodology Improvement Substantiation
}

\section{Використання теорії системної роботи мозку для аналізу єдності між мовними конструкціями введення/виведення: обґрунтування поліпшення методології}

\author{
Ya-Wei Lin \\ Dr. in Education, \\ Professor
}

Я-Вей Лін

доктор педагогічних наук, професор

E-mail: wada.kyohei@gmail.com

https://orcid.org/0000-0002-9642-2245

\section{Oleg Bazaluk}

Dr. in Philosophical Sciences,

Professor
Олег Базалук

доктор філософських наук, професор

E-mail: bazaluk@ukr.net

https://orcid.org/0000-0002-1623-419X

ResearcherID: F-7904-2017

Scopus AuthorID: 56488041400

Guangdong University of

Petrochemical Technology

$\triangle$ No. 139, Guandu Er Lu, Maonan

District, Maoming City, Guangdong

Province, China, 525000
Гуандунський університет нафтохімічних технологій

$\triangle$ №139, Гуанду Ер Лу, Маоман Округ, місто Маомін, провінція

Гуандун, Китай, 525000

Original manuscript received February 05, 2020

Revised manuscript accepted March 08, 2020 


\begin{abstract}
Introduction. Based on the brain science theory of "how people learn" and in order to modernize the methodology of psycholinguistic research, this research used documentary analysis and addressed the standpoint that the 4MAT Teaching and Learning Model can be subsumed into or superimposed on the Kirkpatrick Four-Level Evaluation Model, and vice versa. Meanwhile, the phase of language input and output is analyzed on the basis of the two Models above. In the end, some implications arise so as to provide reference for prospective researchers and practitioners in psycholinguistics.
\end{abstract}

The aim of the study. The 4MAT Teaching and Learning Model and the Kirkpatrick Four-Level Evaluation Model are both widely applied, so a deliberate literature review to clarify the integration and the unity between them is conducted that expects to make some theoretical references inspired by the unity available to a wide range of linguistic teaching design and learning performance evaluation.

The authors argue that the references interconnect teaching design and learning performance evaluation in light of language input and output and therefore help linguistic teachers/trainers with a whole and valid scheme at the very beginning of student learning, and this is the unity that also corresponds to Kirkpatrick \& Kirkpatrick's standpoint: "The end is the beginning".

Research methods. The study was conducted using the semantic differential scaling and the method of documentary analysis.

Results. A combination of brain science theory and Fractal Information Theory has verified initially how the 4MAT Teaching and Learning Model and the Kirkpatrick Four-Level Evaluation Model subsume and superimpose in terms of the theoretical framework, i.e., the unity between a teaching theory and a learning performance evaluation theory. Such integration not only originates from the inherent unity verified by a thoughtful literature review but also receives theoretical support from interdisciplinary studies. Meanwhile, this integration is intertwined with language input and output in a psycholinguistic/neurolinguistic manner.

Conclusions. A primary investigation using brain science theory and other theories to analyze the integration between the 4MAT Teaching and Learning Model and the Kirkpatrick Four-Level Evaluation Model shows the unity between both models. This investigation led to achieving the purpose of the study: modernizing the methodology of psycholinguistic research. With implementing the components/stages of language input and output as this article proposed, it is expected to be promising in extending and applying both models theoretically and practically in linguistics and other relevant areas in the future. As it comes to studies, it is recommended that the two Models be connected to analyze more teaching models and/or learning performance evaluation models for unity, inquire performance evaluation in collaborations with scenarios in practice, or even associate other disciplines under the implementation of Fractal Information Theory. A possible suggestion for psycholinguistic researchers is to design curricular and lessons based on the Unified Models (Figure 1 \& 2) proposed in this study and evaluate instructional efficacy and student learning performance. Another potential research direction is to use each quadrant of the Unified Models and analyze related components in more specific language input and output phases: listening, reading, speaking, writing, and even smaller components in the four types of language 
skills. As it comes to practice, especially in psycholinguistics and/or other relevant disciplines, the key to apply the two target Models simultaneously depends on how to regulate respective quadrants/levels pro rata as well as the wholeness between them to simultaneously achieve "dynamic equilibrium» in the 4MAT Teaching and Learning Model and "The end is the beginning" in the Kirkpatrick Four-Level Evaluation Model.

Key words: psycholinguistics, brain theory, teaching, performance assessment, 4MAT, Kirkpatrick, language constructs, input/output.

\section{Introduction}

To achieve the purpose of the study, this article will incorporate the 4MAT Teaching and Learning Model and the Kirkpatrick FourLevel Evaluation Model with the phase of language input and output into two Unified Models so as to modernize the methodology of psycholinguistic research.

Following the 4MAT System which classifies and defines various learning styles of learners by blending interdisciplinary theories of brain science, neurology, education, administration and psychology (Lin, 2016a; McCarthy, 1980, 2000), the 4MAT Teaching and Learning Model advocates the emotional, mental and physical aspects as the fundamental components of teaching and learning through fractal theory along with the information processing paths in the brain (Caviness, 2007), and employs the concept of how people learn to enhance learning performance in the course of instruction (Czyż \& Svyrydenko, 2019; Kalat, 2013; Lin, 2013, 2016a; Sousa, 2011a; Watson et al., 2019; Wolfe, 2010; Zull, 2002). The Kirkpatrick Four-Level Evaluation Model Reaction (Level 1), Learning (Level 2), Behavior (Level 3), and Results (Level 4) is the most acknowledgeable scale to assess performance after learning/training given to students/trainees which advocates that every and each teacher/trainer with efficacy should evaluate all of the activities in the course of teaching/training for effective learning performance evaluation (Kirkpatrick \& Kirkpatrick, 2006; Kirkpatrick \& Kirkpatrick, 2011, 2019; Sim, 2017).

Firstly, the study deliberately focuses on the two theories, the Caviness 4MAT Teaching and Learning Model (Caviness, 2007) and the Kirkpatrick Four-Level Evaluation Model (Kirkpatrick \& Kirkpatrick, 2006; Kirkpatrick \& Kirkpatrick, 2011, 2019), and elaborates their 
annotations, with providing a definition of language input and output in this article. Secondly, the structural integration between the two Models and «language input and output» (Sousa, 2011b) is investigated. Thirdly, a combination of Fractal Information Theory (FIT) (Agrawal et al., 2018) and brain science theory explores how they inter-subsume (for example (Fatkhutdinov \& Bazaluk, 2018)). Hopefully, steps 1 through 3 above interconnect teaching design and learning performance evaluation in light of language input and output and therefore help linguistic teachers/ trainers with a whole and valid scheme at the very beginning of student learning, and this is the unity that also corresponds to Kirkpatrick \& Kirkpatrick's standpoint: "The end is the Beginning» (Kirkpatrick \& Kirkpatrick, 2011: 60). The 4MAT Teaching and Learning Model and the Kirkpatrick Four-Level Evaluation Model are both widely applied, so a deliberate literature review to clarify the integration and the unity between them is conducted that expects to make some theoretical references inspired by the unity available to a wide range of linguistic teaching design and learning performance evaluation (Chen et al., 2012; Hsiao, 2010; Huang \& Hsieh, 2011; Reio et al., 2017; Sim, 2017; United States, 2008).

\section{Definitions of the Models and Theoretical Frameworks}

In order to modernize the methodology of psycholinguistic research, the two target models implemented for analysis in this article are first introduced in this section before defining language input and output, followed by a description of Fractal Information Theory (FIT) used as the carrier of the two target models and the phase of language input and output.

\section{4MAT Teaching and Learning Model}

The primary theoretical source of the 4MAT Teaching and Learning Model is the 4MAT System (Caviness, 2007; Lin, 2013, 2016a; McCarthy, 2000). On the basis of Kolb's concepts of the structure of learning, i.e., his Experiential Learning Model (Watson et al., 2019), the McCarthy 4MAT System employs the concepts of plane geometry to classify how one learns into 4 quadrants:

Quadrant one (Q1) as «the highly imaginative student who favors feeling and reflecting,» Quadrant two (Q2) as «the analytic student who favors reflecting and thinking,» Quadrant three (Q3) as 
«the common-sense learner who favors thinking and doing» and Quadrant four (Q4) as «the dynamic learner who favors creating and acting» (Lin, 2013: 32; Lin, 2016a: 5; McCarthy, 1997: 46-48; McCarthy, 2000).

A combination of the McCarthy 4MAT System and the clockwise information processing direction in the brain (Zull, 2002) made by Caviness (2007) contributing to her teaching/learning steps of Q1-Q4 in the 4MAT Teaching and Learning Model expects to give teachers of any field a foundation of brain science theory with regard to instructional activity design (Lin, 2016a). Q1 is the emotional aspect of learning that corresponds to the sensory integration zone (starting from the somatosensory cortex) in charge of information processing in the cerebral cortex; Q2 is the mental aspect of learning that corresponds to the conceptual integration zone (mainly the prefrontal cortex) in charge of information processing in the cerebral cortex; Q3 is the physical aspect of learning that corresponds to the motor integration zone (the motor cortex sends commands to the body) in charge of information processing in the cerebral cortex (Caviness, 2001, 2007; Lin, 2013, 2016a; Zull, 2002). Q4 is service learning that contributes learning results to others and is the end fruit of the whole brain (Caviness, 2007; Lin, 2013, 2016a). The 4 quadrants are stated as follows:

Quadrant 1: the Emotional aspect values the connection between what has been known and what is to be known for a learner with the importance of the incoming information explicitly defined, i.e., the meaning of that learning (Caviness, 2007). According to the 4MAT Teaching and Learning Models by Caviness (2007) and Lin (2013), the latter of whom names Q1 the Affective aspect, the authors also name Q1 the Affective aspect, or Affect (Lin, 2013, 2016a).

Quadrant 2: the Mental aspect values the content of learning. In such phase, it is common for a teacher to teach information in a oneway manner (Caviness, 2007). Following the Lin 4MAT Teaching and Learning Model (2013), the authors also name Q2 the Cognitive aspect, or Cognition (Lin, 2013, 2016a).

Quadrant 3: the Physical aspect highlights drills of skills and explicit performance of what is learnt in reality (Caviness, 2007). In accordance with the Lin 4MAT Teaching and Learning Model (2013), the authors also name Q3 the Behavioral aspect, or Behavior (Lin, 2013, 2016a). 
The learning aspects subsumed by Q1, Q2 and Q3 are supported by other theories that agree to the affective, cognitive and skill-based types of learning results. As it comes to the discipline of organizational communication, the Inventory of Change in Organizational Culture classifies reaction to change into the affective, cognitive and behavioral respects (Driskill, 2019).

Quadrant 4: the Service Learning aspect in the Caviness 4MAT Teaching and Learning Model pinpoints how a learner conducts personal extension and application of what is learnt, conveys what has been learnt to others, and contributes to others (Caviness, 2007). This is named by Caviness «Disequilibrium» and by Lin «Balance \& Disequilibration» equivalent to «dynamic equilibrium» or «disequilibrated equilibrium,» respectively (Lin, 2013, 2016a).

\section{Kirkpatrick Four-Level Evaluation Model}

The Kirkpatrick Four-Level Evaluation Model published by Kirkpatrick in 1959 with Levels 1-4, Level 1: Reaction, Level 2: Learning, Level 3: Behavior, and Level 4: Results, is the most adopted evaluation model for the official training institutions acknowledged officially by the United States (United States, 2008) while some paper pinpoints its application to the education discipline as well (Reio et al., 2017).

Each level of the Kirkpatrick Four-Level Evaluation Model interlinks closely where each has its unique impact on the next inevitably (Hsiao, 2010). The authors annotate Levels 1-4 of the Kirkpatrick Four-Level Evaluation Model specifically as follows (Kirkpatrick \& Kirkpatrick, 2006; Kirkpatrick \& Kirkpatrick, 2011, 2019):

\section{Level 1: Reaction}

Reaction refers to how a learner perceives the course attended in person, i.e., the personal satisfaction or preference level. The evaluation core of Level 1 covers multiple respects including but not limited to the overall curriculum structure of teaching/training, the quality of the teacher, the anchors (goal anchoring), the theme arrangement, the content setting, the timeline planning, the instructional skills/ techniques, the teaching hardware (instruments/materials), the ambient hardware (environment/equipment), administration/management and miscellaneous backup (administrative support); however, in this phase, 
merely how a learner senses learning is inspected but how the content is comprehended or mastered remains unevaluated (Chen et al., 2012; Huang \& Hsieh, 2011).

\section{Level 2: Learning}

Level 2 essentially evaluates how a student or a trainee performs in terms of the affective, cognitive and skill-based aspects where the affective results include attitude and motivation, the cognitive results include knowledge and strategies and the skill-based results include technique and operation; however, in this phase, merely how a learner performs after learning is inspected but how the content learnt is used remains unevaluated (Chen et al., 2012).

\section{Level 3: Behavior}

In accordance with Huang \& Hsieh (2011), Level 3 evaluates how a student/trainee enhances any competence or behavior materially after attending the course with the following questions reviewed:

"Can their transfer of learning appear out of the evaluated teaching process? Can their attitude, knowledge or skills acquired in this Level be used in real life? Can their behavior be improved out of the evaluated learning process?».

It requires adequate time given to a learner for behavioral change (Huang \& Hsieh, 2011; Kirkpatrick \& Kirkpatrick, 2006); however, in this phase, merely how a learner performs personally after learning is inspected but how individuals perform in non-individual circumstances (organizations/groups) remains unevaluated and this is to be evaluated in Level 4.

\section{Level 4: Results}

Level 4 evaluates the following questions:

"Can a learner acquire the attitude, skills and knowledge (Level 2) out of the learning process? Can Level 2 result in behavioral change (Level 3)? Can a learner perform for the organization (not for oneself)?»(Chen et al., 2012)

According to Hsiao (2010), a positive correlation between each evaluation level and its complexity is proven, so the higher the evaluation level is, the more complexity it has. Additionally, as aforementioned in Level 3, it requires adequate time given to a learner for significant performance (Chen et al., 2012). 


\section{Language Input and Output}

Language input includes listening and reading, and language output entails speaking and writing (Sousa, 2011b). Language input processes in the following pathway:

"(acoustic/visual) analysis and decoding," "(phonological/ orthographic) coding,» «(auditory/visual) word form activated,» «lexicon recognizing word,» «syntactic and semantic networks activated,» and finally «concept formation» (Gazzaniga et al., 2002; Sousa, 2011b: 21-22, 89).

\section{Fractal Information Theory (FIT) as the Carrier of How the} 4MAT Teaching and Learning Model, the Kirkpatrick Four-Level Evaluation Model, and Language Input and Output Inter-Subsume

Fractal Information Theory (FIT) has the features as follows fitted to be the carrier to how the 4MAT Teaching and Learning Model, the Kirkpatrick Four-Level Evaluation Model, and language input and output inter-subsume (Agrawal et al., 2018; Caviness, 2007; McCarthy \& O’Neill-Blackwell, 2007; Sousa, 2011b). A fractal, geometrically a subset of a topology similar or identical to the original, appears the same even at different levels. Its conception means the unlimited replication or extension of self-similarity. As for its application, it can connect theories or make levels with similarities or identical conceptions correspond, subsume or superimpose (Agrawal et al., 2018; Caviness, 2001, 2007; Lin, 2016a).

Caviness $(2001,2007)$ employs Fractal Information Theory to relate different human learning levels. With a triangle as the architecture for the components to inter-subsume, Levels 1-3 of Learning, Parts 1-3 in Neuron, Parts 1-3 in Brain, and Parts 1-3 of Mankind are interimposed to form a successive expanding multi-triad. The aspects of the Caviness triad of learning are specified below (Caviness, 2007; Lin, 2013, 2016a; Kalat, 2013; Sousa, 2011a; Wolfe, 2010; Zull, 2002):

(a) Affective/Emotional: Dendrite in Neuron (the sensory integration zone at the neuron level) in charge of receiving information, Limbic system in Brain (in charge of emotions in the sensory integration zone at the brain level) and Heart of Mankind.

(b) Cognitive/Mental: Soma in Neuron (the conceptual integration zone at the neuron level) in charge of conveying information 
or not, Cortex in Brain (the conceptual integration zone at the brain level), and Brain of Mankind.

(c) Behavioral/Physical: Axon in Neuron (the motor integration zone at the neuron level), Brain Stem in Brain (the motor integration zone at the brain level), and Body of Mankind.

Caviness (2007) relates the key components in Mankind, Brain and Neuron that interconnect in terms of their meanings: Heart (Affect), Brain (Cognition) and Body (Behavior) in Mankind; Limbic System (Affect), Cortex (Cognition) and Brain Stem (Behavior) in Brain; and Dendrite (Affect), Soma (Cognition) and Axon (Behavior) in Neuron (Lin, 2016a). As aforementioned in the nature of fractals, the fractal conception can be applicable for Mankind, Brain and Neuron as well: Mankind, Brain and Neuron identical to fractals appear the same even at different levels (Caviness, 2001, 2007; Lin, 2013, 2016a).

With Neuron, Brain and Mankind that conceptually interconnect and correspond, it is suitable to employ Fractal Information Theory as the carrier to explicate how the 4MAT Teaching and Learning Model, the Kirkpatrick Four-Level Evaluation Model, and language input and output mutually inter-subsume and inter-superimpose is adequate: (1) Affect in the 4MAT Teaching and Learning Model inter-corresponds to Reaction in the Kirkpatrick Four-Level Evaluation Model and to the initial and major stages of language input (affective/sensory input, inclusive of listening and reading) processing before concept formation, (2) Cognition in the 4MAT Teaching and Learning Model intercorresponds to Learning in the Kirkpatrick Four-Level Evaluation Model and to mental concept formation of language input processing, which prepares to output language (cognitive process), and (3) Behavior in the 4MAT Teaching and Learning Model inter-corresponds to Behavior in the Kirkpatrick Four-Level Evaluation Model and to language output: speaking and writing (behavioral skills in language performance). Consequently, the authors utilize Fractal Information Theory as the carrier of how the 4MAT Teaching and Learning Model, the Kirkpatrick Four-Level Evaluation Model, and language input and output intersubsume in this study (Lin, 2016b; McCarthy \& O'Neill-Blackwell, 2007; Sousa, 2011b). 
Using Brain Science Theory and Fractal Information Theory to Analyze How the 4MAT Teaching and Learning Model, the Kirkpatrick Four-Level Evaluation Model, and Language Input and Output Inter-Subsume and Inter-Superimpose: Unity and Wholeness

1. How Quadrants 1-4 in the 4MAT Teaching and Learning Model Correspond to Levels $1-4$ in the Kirkpatrick Four-Level Evaluation Model and to Language Input and Output.

There are four components in the 4MAT Teaching and Learning Model and the Kirkpatrick Four-Level Evaluation Model (4 quadrants and 4 levels), so the authors adopt a quadriad to make them subsume and superimpose using brain science theory and Fractal Information Theory and manages to make each quadrant in the 4MAT Teaching and Learning Model connect with and correspond to each level in the Kirkpatrick Four-Level Evaluation Mode. Meanwhile, the concepts of language input and language output can superimposed on the two Models as all of them inter-subsume. The procedure is as follows (Caviness, 2007, Lin, 2013, 2016a, 2016b; McCarthy \& O’Neill-Blackwell, 2007; Sousa, 2011b):

(a) Q1 in the 4MAT Teaching and Learning Model/Level 1 in the Kirkpatrick Four-Level Evaluation Model (Sensory Integration teaching phase/learning phase/learning performance evaluation phase):

Quadrant 1: Affect in the 4MAT Teaching and Learning Model corresponds to Level 1 Reaction in the Kirkpatrick Four-Level Evaluation Model (Lin, 2016a, 2016b; McCarthy \& O’NeillBlackwell, 2007). Reaction values how a learner senses affectively and thus corresponds to Affect. Evaluation of Reaction includes the methods of interviews, opinion sheets, or questionnaires that examine «Satisfaction» and "If learning motivates or interests the trainees» (Hsiao, 2010: 4; Kirkpatrick \& Kirkpatrick, 2006). «Satisfaction» is Affect in Q1 and Reaction in Level 1. The concept «If learning motivates or interests the trainees» connects with curiosity and intrinsic motivation of Q1 in the 4MAT Teaching and Learning Model (Caviness, 2007; Hsiao, 2010: 4). With regard to learning in general, sensory (auditory/visual) input drives emotion (Caviness, 2001, 2007; Kalat, 2013, Lin, 2013), and therefore the initial and major stages of language input 
processing (before concept formation) can be categorized into Quadrant 1/Level 1 (Sousa, 2011b). Delving deeper, "Emotion drives attention and attention drives learning» (Sylwester, 1995: 72). This corresponds to Affect valued by Q1 in the 4MAT Teaching and Learning Model. An attentive learner results from curiosity aroused by the learning process (Caviness, 2007), agreed by Lin (2013) as well. Later, «Relevance» and «Engagement» are added to Reaction (Kirkpatrick \& Kirkpatrick, 2011, 2019). Relevance conceptually corresponds to what is subsumed by Q1 in the 4MAT Teaching and Learning Model: A learner connects what is known and comprehends the importance of what is to be known and its relatedness (Caviness, 2007). Engagement conceptually connects with curiosity as Arnone, Small, Chauncey and McKenna (Arnone et al., 2011) identify Curiosity as mutualism between Interest and Engagement. As far as learning is concerned, language input shares the same affective components, Interest and Engagement, in the process of language learning.

(b) Q2 in the 4MAT Teaching and Learning Model/Level 2 in the Kirkpatrick Four-Level Evaluation Model (Conceptual Integration teaching phase/learning phase/learning performance evaluation phase):

Quadrant 2: Cognition in the 4MAT Teaching and Learning Model that values learning and gaining of knowledge and conception in terms of the affective, cognitive and skill-based aspects corresponds to Level 2 Learning in the Kirkpatrick Four-Level Evaluation Model and to mental concept formation of language input processing, which prepares to output language (Lin, 2016a, 2016b; McCarthy \& O’Neill-Blackwell, 2007; Sousa, 2011b). Learning covers personal enhancement in terms of the affective, cognitive and skill-based aspects for learners (Chen et al., 2012). This is a presentation of Fractal Information Theory: Replication of the components covered by Q1-Q3 in the 4MAT Teaching and Learning Model identified in Level 2 in the Kirkpatrick FourLevel Evaluation Model. Evaluation of Learning includes the methods of the observational method, simulation practice, pretest and posttest sheets, or questionnaires (Hsiao, 2010) that evaluate attitude, knowledge and skills and conceptually corresponds to Q2 (What?) in the Caviness 4MAT Teaching and Learning 
Model (Caviness, 2007, p. 25). The three-aspected components of teaching and learning above are honored and can be applied in the process of language teaching and learning as in language learning mental concept formation is connected to the affective, cognitive and skill-based aspects as well (Sousa, 2011b).

(c) Q3 in the 4MAT Teaching and Learning Model/Level 3 in the Kirkpatrick Four-Level Evaluation Model (Behavioral Integration teaching phase/learning phase/learning performance evaluation phase):

Quadrant 3: Behavior in the 4MAT Teaching and Learning Model corresponds to Level 3 Behavior in the Kirkpatrick Four-Level Evaluation Model and to language output: speaking and writing in this study (Lin, 2016a, 2016b; McCarthy \& O'Neill-Blackwell, 2007; Sousa, 2011). Behavior values personal behavioral change and thus corresponds to Q3 in the 4MAT Teaching and Learning Model: Use what is learnt with explicit behavior. Evaluation of Behavior includes the methods of the observational method, questionnaires, focus group, and experimental comparison (Chen et al., 2012; Hsiao, 2010). Implementation includes action plans and competency testing that identify transfer of learning and this corresponds to the emphasis of Skill-based in Q3 in compliance with the question asked by Q3 (How?) in the Caviness 4MAT Teaching and Learning Model (Caviness, 2007, p. 25). The skill-based emphasis can be directly linked to teaching and/ or learning speaking and writing (language output) as behavioral skills in language education/performance.

It requires the following 4 Terms that exist simultaneously for behavioral change by learning (Kirkpatrick \& Kirkpatrick, 2006): Term 1, a learner is in the right mood; Term 2, a learner is fond of change; Term 3, a learner is inspired; and Term 4, a learner is aware of what to do and how to do. Given that, how Level 3 Behavior in the Kirkpatrick Four-Level Evaluation Model corresponds to Q1-Q3 in the 4MAT Teaching and Learning Model is stated as follows: Term 1 corresponds to Q1, i.e., the ambient setting that is good enough and assures positive affection, as is connected to sensory input in language teaching and learning; Term 2 corresponds to intrinsic motivation valued by Q1; Terms 3 corresponds to extrinsic motivation valued by Q2 \& Q3 and returns 
to affect and intrinsic motivation in Q1; and Term 4 corresponds to «What?», which is connected to concept formation in language teaching and learning, and «How?», which is connected to language output in language teaching and learning, subsumed by Q2 \& Q3, respectively (Caviness, 2007: 25; Kirkpatrick \& Kirkpatrick, 2006; Lin, 2013, 2016a). Consequently, this is a presentation of Fractal Information Theory indeed: Replication of Q1-Q3 (Affect, Cognition and Behavior) both in the 4MAT Teaching and Learning Model and in the phase of language input and output is subsumed conceptually in Level 3 Behavior in the Kirkpatrick Four-Level Evaluation Model.

(d) Q4 in the 4MAT Teaching and Learning Model/Level 4 in the Kirkpatrick Four-Level Evaluation Model (Whole Integration teaching phase/learning phase/learning performance evaluation phase):

Quadrant 4: Service Learning in the 4MAT Teaching and Learning Model that values personal application and contribution to others (Caviness, 2007) corresponds to Level 4 Results in the Kirkpatrick Four-Level Evaluation Model: A person performs for a group (organization), and to the whole integration of language input and output in language education (Kirkpatrick \& Kirkpatrick, 2011, 2019; Lin, 2016a, 2016b; McCarthy \& O’Neill-Blackwell, 2007; Sousa, 2011b). Evaluation of Results includes the methods of questionnaires, experimental comparison and pretest and posttest comparison that examine personal performance for organizations/ groups (Chen et al., 2012).

Service Learning is specifically elaborated:

«as the learner moves focus away from intake for personal improvement and toward output for the benefit of others, mutual benefit occurs - among teacher, student, and class members» (Caviness, 2007: 26).

Caviness also indicates that Q4 in the 4MAT Teaching and Learning Model receives the least attention during learning in particular. Within all Levels in the Kirkpatrick Four-Level Evaluation Model, Level 4 Results is the most challenging to attain (Hsiao, 2010). The concept that 
«Each Level in the Kirkpatrick Four-Level Evaluation Model is sequential and each impacts the next» (Hsiao, 2010: 3)

is identical to brain science theory in the 4MAT Teaching and Learning Model since the sequential order of Q1-Q4 equals to the information processing procedure in the brain and thus refers to priority intrinsically given as it comes to time and inherent logic. The processing of language input and output follows the same manner (Caviness, 2007; Zull 2002; Sousa, 2011b).

The figure of how the 4MAT Teaching and Learning Model, the Kirkpatrick Four-Level Evaluation Model and Language Input and Output correspond with Fractal Information Theory as the carrier is Figure 1.

Q4: Integration of Language Input and Output
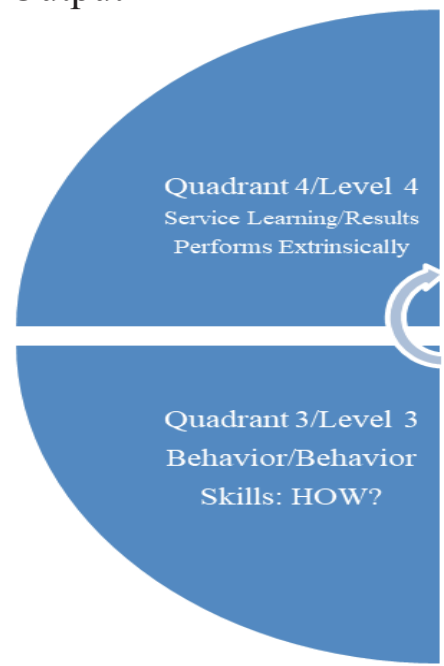

Q3: Language Output
Q1: Major Stages of Language

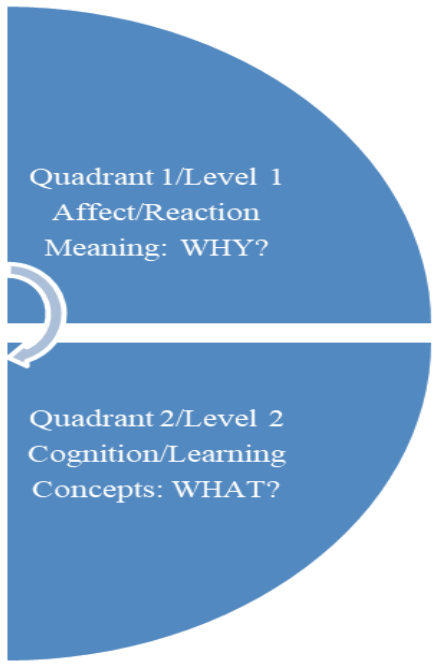

Q2: Language Input to Output (Concept Formation)

Figure 1. Diagram of how the 4MAT Teaching and Learning Model and the Kirkpatrick Four-Level Evaluation Model integrate (Agrawal et al., 2018; Caviness, 2001; Caviness, 2007: 25;

Gazzaniga et al., 2002; Kirkpatrick \& Kirkpatrick, 2006; Kirkpatrick \& Kirkpatrick, 2011, 2019; Lin, 2013: 33; Lin, 2016a: 10; Lin, 2016b; McCarthy, 2000; McCarthy \& O'Neill-Blackwell, 2007; Sousa, 2011a, 2011b; Zull, 2002) 
2. Application of Dynamic Equilibrium (Disequilibrated Equilibrium) to the 4MAT Teaching and Learning Model, the Kirkpatrick Four-Level Evaluation Model, and Language Input and Output

Effective teaching requires balance between 4 quadrants in the 4MAT Teaching and Learning Model and intrinsic and extrinsic motivation simultaneously (Caviness, 2007). That is, each matters the same (Lin, 2016a). A combination of such concept and the correlation between the 4MAT Teaching and Learning Model and the Kirkpatrick Four-Level Evaluation Model shows that equilibrated Levels 1-4 in the Kirkpatrick Four-Level Evaluation Model are also required and each matters the same. Similarly, the four quadrants of language input and output shown in Figure 1 can be considered and implemented in this manner.

Caviness (2007) points out that a creature needs disequilibrium or remains non-stagnated for sustainability. Glasser (1986) identifies the co-existence pro rata of and the interdependence across «feeling» (affect), «thought» (cognition), «action» (behavior), and «physiological activity» for mankind, which forms our wholeness. This is dynamic equilibrium in the 4MAT Teaching and Learning Model (Caviness, 2007; Glasser, 1986: 45; Lin, 2013; Lin, 2016a: 15).

The aforementioned perspective of Glasser (1986) corresponds to Q1-Q3 integrated as Q4 in the 4MAT Teaching and Learning Model (Caviness, 2007). Levels 1-3 eventually lead to Level 4 in the Kirkpatrick Four-Level Evaluation Model as well - and so are the 4 language input and output stages (Chen et al., 2012; Sousa, 2011b). In the 4MAT Teaching and Learning Model, Caviness pinpoints that Q4 values dynamic equilibrium across the components in Q1-Q3 (Caviness, 2007). Level 4 Results in the Kirkpatrick Four-Level Evaluation Model also covers the components in Levels 1-3 pro rata: Any person performs for any organization with a learning/training activity given specifically must undergo Level 1: perception of such activity, Level 2: enhancement of the attitude, knowledge or skills due to such procedure, and Level 3: personal behavioral change by such activity (Chen et al., 2012). As identified by Kirkpatrick and Kirkpatrick (2006, 2011, 2019), every and each linguistic training/learning activity requires the design, exercise and performance evaluation aspects that interlink to and/or 
interconnect with Levels 1-4 in the Kirkpatrick Four-Level Evaluation Model. This is also a presentation of Fractal Information Theory and Glasser's perspective: Each learning activity or any teaching procedure covers tacit conceptions of the Kirkpatrick Four-Level Evaluation Model a.k.a. replication of a self-similar quadriad (Caviness, 2007; Glasser, 1986; Lin, 2013, 2016a, 2016b; McCarthy \& O’Neill-Blackwell, 2007).

White (1903) defines education as

"True education ... is the harmonious development of the physical, the mental, and the spiritual powers» (Lin, 2016a: 8; White, 1903: 3)

and this definition values wholeness of the affective (spiritual), cognitive (mental) and behavioral (physical) aspects as well (Bazaluk \& Blazhevych, 2015). A combination of Fractal Information Theory, education defined by White, and the 4 components advocated by Glasser a.k.a. feeling (affect), thinking (cognition), acting (behavior) and physiology that forms the dynamic equilibrium dependence assertion evidences the importance of dynamic equilibrium between/among the components of any system. This also supports the wholeness and the unity between the 4MAT Teaching and Learning Model and the Kirkpatrick Four-Level Evaluation Model in terms of affect, cognition and behavior and in terms of language input and output stages.

3. Wholeness of Integration Between the 4MAT Teaching and Learning Model and the Kirkpatrick Four-Level Evaluation Model and Inter-Subsumption among the Two Models and Language Input and Output.

Pursuant to Lin (2013), how Q1-Q3 in the 4MAT Teaching and Learning Model (Caviness, 2007) correspond to social learning theory (Derry, 2013), cognitive development theory (Hanfstingl et al., 2019) and behaviorism (Baum, 2016), respectively, is stated as follows (Lin, 2016a). In accordance with the theoretical foundation aforementioned, the three theories correspond to Levels 1-3 in the Kirkpatrick FourLevel Evaluation Model as well. In other words, Level 1 Reaction in the Kirkpatrick Four-Level Evaluation Model subsumes social learning theory (Derry, 2013) and thus corresponds to the Heart of mankind, the Limbic System in the brain and Dendrites in the neuron, and then to the initial and major stages of language input; Level 2 Learning subsumes 
cognitive development theory (Hanfstingl et al., 2019) and thus corresponds to the Brain of mankind, the Cortex in the brain and the Soma in the neuron, and then to the stage of language input to output (concept formation); Level 3 Behavior subsumes behaviorism (Baum, 2016) and thus corresponds to the Body of mankind, the Brain Stem in the brain and the Axon in the neuron, and then to language output (Baum, 2016; Caviness, 2007; Derry, 2013; Lin, 2013, 2016a, 2016b; McCarthy \& O’Neill-Blackwell, 2007; Sousa, 2011b). Additionally, how brain processes information, how Levels 1-4 develop, and how language input/output processes are alike and their final outcomes are performed extrinsically equivalent to Service Learning and Results (Perform) in the 4MAT Teaching and Learning Model and the Kirkpatrick FourLevel Evaluation Model, respectively (Caviness, 2007; Kirkpatrick \& Kirkpatrick, 2011, 2019) (Fig. 2).

A deliberate literature review in the preceding paragraphs has identified the 4MAT Teaching and Learning Model with the theoretical foundation of learning performance evaluation as well as the Kirkpatrick Four-Level Evaluation Model with the foundation of teaching design, with implementing into the two Models the components/stages of language input and output. How they inter-subsume and integrate each other not only conforms to interconnectedness (the unity across all) in the 4MAT Teaching and Learning Model using Fractal Information Theory and brain science theory but also corresponds to the oneness between teaching evaluation and teaching design a.k.a. the core idea valued by Kirkpatrick and Kirkpatrick (Caviness, 2007; Lin, 2016a, 2016b; Kirkpatrick \& Kirkpatrick, 2011, 2019).

\section{Conclusions and Suggestions}

The 4MAT Teaching and Learning Model published around 40 years ago has the theoretical source of the 4MAT System and its application to teaching has been widely studied and receives the interdisciplinary theoretical foundation including brain science (Caviness, 2007; Lin, 2013, 2016a; McCarthy \& O’Neill-Blackwell, 2007). The Kirkpatrick Four-Level Evaluation Model was published 60 years ago and its wide application to learning performance evaluation has been proven as well (Chen et al., 2012; Hsiao, 2010; Huang \& 
Hsieh, 2011; Lin, 2016b; Reio et al., 2017; United States, 2008). Given that, a combination of brain science theory and Fractal Information Theory has verified initially how the 4MAT Teaching and Learning Model and the Kirkpatrick Four-Level Evaluation Model subsume and superimpose in terms of the theoretical framework, i.e., the unity between a teaching theory and a learning performance evaluation theory. Such integration not only originates from the inherent unity verified by a thoughtful literature review but also receives theoretical support from interdisciplinary studies. Meanwhile, this integration is intertwined with language input and output in a psycholinguistic/neurolinguistic manner.

Q4: Integration of Language Input and Output
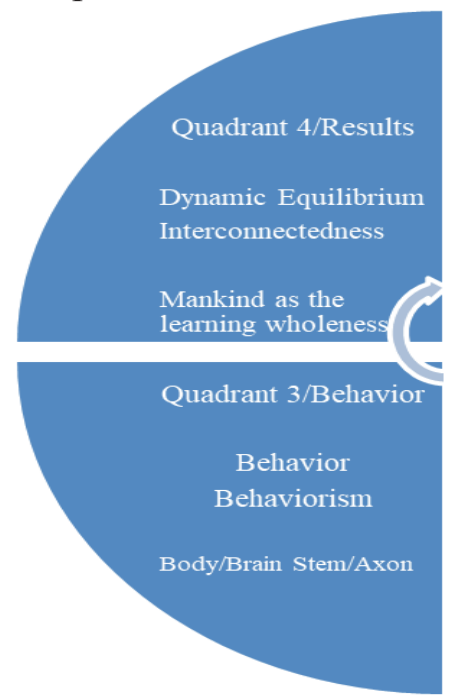

Q3: Language Output
Q1: Major Stages of Language Input

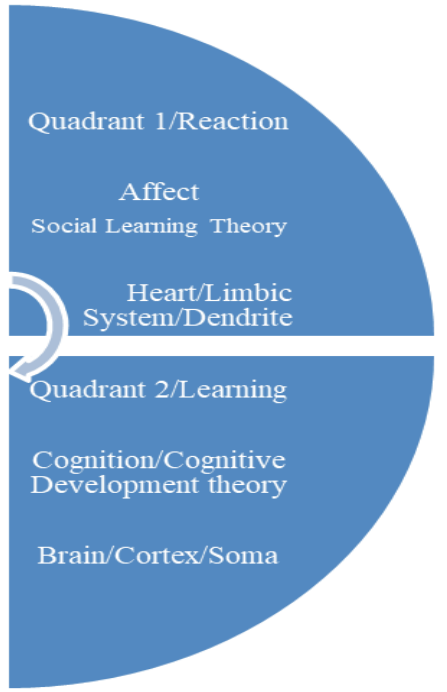

Q2: Language Input to Output (Concept Formation)

Figure 2. Wholeness of how the 4MAT Teaching and Learning Model, the Kirkpatrick Four-Level Evaluation Model, social learning theory/cognitive development theory/behaviorism, and language input and output inter-subsume and inter-superimpose (Agrawal et al., 2018; Caviness, 2001; Caviness, 2007: 25;

Gazzaniga et al., 2002; Glasser, 1986; Kirkpatrick \& Kirkpatrick, 2006; Kirkpatrick \& Kirkpatrick, 2011, 2019; Kalat, 2013; Lin, 2013: 33; Lin, 2016a: 10; Lin, 2016b: 3; McCarthy, 2000; McCarthy \& O'Neill-Blackwell, 2007; Baum, 2016; Sousa, 2011a, 2011b; Derry, 2013; Wolfe,2010; Zull, 2002). 
A primary investigation using brain science theory and other theories to analyze the integration between the 4MAT Teaching and Learning Model and the Kirkpatrick Four-Level Evaluation Model shows the unity between both models. This investigation led to achieving the purpose of the study: modernizing the methodology of psycholinguistic research. With implementing the components/stages of language input and output as this article proposed, it is expected to be promising in extending and applying both models theoretically and practically in linguistics and other relevant areas in the future. As it comes to studies, it is recommended that the two Models be connected to analyze more teaching models and/or learning performance evaluation models for unity, inquire performance evaluation in collaborations with scenarios in practice, or even associate other disciplines under the implementation of Fractal Information Theory (Lin, 2016b). A possible suggestion for psycholinguistic researchers is to design curricular and lessons based on the Unified Models (Figure 1 and 2) proposed in this study and evaluate instructional efficacy and student learning performance. Another potential research direction is to use each quadrant of the Unified Models and analyze related components in more specific language input and output phases: listening, reading, speaking, writing, and even smaller components in the four types of language skills.

As it comes to practice, especially in psycholinguistics and/ or other relevant disciplines, the key to apply the two target Models simultaneously depends on how to regulate respective quadrants/levels pro rata as well as the wholeness between them to simultaneously achieve «dynamic equilibrium» in the 4MAT Teaching and Learning Model and «The end is the beginning» in the Kirkpatrick Four-Level Evaluation Model (Caviness, 2007; Kirkpatrick \& Kirkpatrick, 2011: 60; Kirkpatrick \& Kirkpatrick, 2019; Lin, 2013, 2016a, 2016b).

«Dynamic equilibrium» in the 4MAT Teaching and Learning Model (Caviness, 2007; Lin, 2013, 2016a) and "The end is the beginning» in the Kirkpatrick Four-Level Evaluation Model (Kirkpatrick \& Kirkpatrick, 2011: 60; Kirkpatrick \& Kirkpatrick, 2019) as well as the unity between them in particular can be identified as the important reference to the conception of teaching design and learning performance evaluation in psycholinguistics (Aish \& Hanna, 2017). The long-term interdisciplinary studies associated therewith and the inter-subsuming contents thereof evidence the 4MAT Teaching and Learning Model and the Kirkpatrick 
Four-Level Evaluation Model with reliability and validity as applied to teaching and learning performance evaluation. The authors suggest simultaneous application to more teaching links such as the aspects of curriculum design, teaching design and learning performance evaluation and expects future studies to identify their performance in psycholinguistic and/or other relevant areas.

\section{References}

Agrawal, L., Chhajed, R., Ghosh, S., Ghosh, B., Ray, K., Sahu, S., \& Fujita, D. (2018). Fractal Information Theory (FIT)-Derived Geometric Musical Language (GML) for Brain-Inspired Hypercomputing. In Pant M., Ray K., Sharma T., Rawat S., \& Bandyopadhyay A. (Eds), Proceedings of SoCTA' 18 «Soft Computing: Theories and Applications». Part of Advances in Intelligent Systems and Computing (Vol. 584, pp. 343-372). Springer. Singapore. https://doi. org/10.1007/978-981-10-5699-4_33

Aish, R., \& Hanna, S. (2017). Comparative evaluation of parametric design systems for teaching design computation. Design Studies, 52, 144-172. https://doi. org/10.1016/j.destud.2017.05.002

Arnone, M.P., Small, R.V., Chauncey, S.A., \& McKenna, H.P. (2011). Curiosity, interest and engagement in technology-pervasive learning environments: A new research agenda. Educational Technology Research and Development, 59 (2), 181-198. https://doi.org/10.1007/s11423-011-9190-9

Baum, W. (2016). Understanding Behaviorism: Behavior, Culture, and Evolution. Third Edition. John Wiley \& Sons, Inc. https://doi.org/10.1002/9781119143673

Bazaluk, O., \& Blazhevych, T. (2015). Modern Basics of the Philosophy of Education. Future Human Image, 2 (5), 93-100.

Caviness, L.B. (2001). Educational brain research as compared to E.G. White's counsels to educators. Doctor's thesis. Available from ProQuest Dissertation and theses database (UMI No. 3019334).

Caviness, L.B. (2007). A qualitative analysis of whole-child nurture from brain science perspective. In A. Nava (Ed.), Critical Issues in Brain Science and Pedagogy (pp. 5-31). New York, NY: McGraw-Hill.

Chen, T.L., Jeang, S.G., \& Liu, Y.L. (2012). A training evaluation study based on Kirkpatrick's four-level evaluation model in public sector training. Review of Agricultural Extension Science, 29, 22-44 [in Chinese].

Czyż, A., \& Svyrydenko, D. (2019). Science Education as a Response to the Needs of the Modern Open «Education for Everyone» System. Future Human Image, 11, 14-21. https://doi.org/10.29202/fhi/11/2

Derry, J. (2013). Vygotsky: Philosophy and Education. Wiley-Blackwell. https://doi. org/10.1002/9781118368732

Driskill, G.W. (2019). Organizational Culture in Action. New York: Routledge. https:// doi.org/10.4324/9780429427473

Fatkhutdinov, V., \& Bazaluk, O. (2018). The Importance of the Brain NeuroProgramming Technologies in National and Regional Security Strategies. Philosophy and Cosmology, 20, 74-82. https://doi.org/10.29202/phil-cosm/20/6 
Using Brain Science Theory to Analyze the Unity between Language...

Gazzaniga, M.S., Ivry, R.B., \& Mangun, G.R. (2002). Cognitive neuroscience: The biology of the mind ( $2^{\text {nd }}$ ed.). New York: Norton.

Glasser, W. (1986). Control theory in the classroom. New York, NY: Harper \& Row.

Hanfstingl, B., Benke, G., \& Zhang, Y. (2019) Comparing variation theory with Piaget's theory of cognitive development: more similarities than differences? Educational Action Research, 27 (4), 511-526. https://doi.org/10.1080/09650792 .2018 .1564687

Hsiao, Y.C. (2010). The implication of public sector training evaluated by Kirkpatrick levels. T\&D Fashion, 90, 1-17. [in Chinese].

Huang, J.T., \& Hsieh, H.H. (2011). Training evaluation of management development training program: A case study of public sector training institution. Journal of Human Resource Management, 11, 1-26. [in Chinese].

Kalat, J.N. (2013). Biological psychology (11 th ed.). Belmont, CA: Wadsworth CENGAGE Learning.

Kirkpatrick, D.L., \& Kirkpatrick, J.D. (2006). Evaluating training programs: The four levels ( $3^{\text {rd }}$ ed.). San Francisco, CA: Berrett-Koehler Publishers, Inc.

Kirkpatrick, J.D., \& Kirkpatrick, W. (2011). Creating ROE: The end is the beginning, $T+D, 65(11), 60-64$.

Kirkpatrick, J.D, \& Kirkpatrick, W. (2019). An introduction to the New World Kirkpatrick Model. Newnan, GA: Kirkpatrick Partners: The One and Only Kirkpatrick.

Lin, Y.W. (2013). The effects of cognitive flexibility and openness to change on college students' academic performance. Doctor's thesis.

Lin, Y.W. (2016a). Analysis of the curriculum design of the Academy of Civil Service's personnel management skills development and training program for newly appointed supervisors using the 4MAT teaching and learning model. $T \& D$ Fashion, 214, 1-32 [in Chinese]

Lin, Y.W. (2016b). The development and application of the exploration and action learning course: The 2012-2015 research results of the Academy of Civil Service's personnel management skills development and training program for newly appointed supervisors. T\&D Fashion, 223, 1-29 [in Chinese].

McCarthy, B. (1980). The 4MAT system. Oakbrook, IL: Excel.

McCarthy, B. (1997). A table of four learners: 4MAT's learning style. Educational Leadership, 54 (6), 46-51.

McCarthy, B. (2000). About teaching. Wauconda, IL: About Learning Inc.

McCarthy, B., \& O'Neill-Blackwell, J. (2007). Hold on, you lost me: Use learning styles to create training that sticks. Alexandria, VA: ASTD Press.

Reio, T.G., Rocco, T.S., Smith, D.H., \& Chang, E. (2017), A Critique of Kirkpatrick's Evaluation Model. New Horizons in Adult Education and Human Resource Development, 29, 35-53. https://doi.org/10.1002/nha3.20178

Sim, J. (2017). Using Kirkpatrick Four Level Evaluation model to assess a 12-week accelerated ultrasound intensive course. Sonography, 4, 110-119. https://doi. org/10.1002/sono. 12116

Sousa, D.A. (2011a). How the brain learns (4th ed.). Thousand Oaks, CA: Corwin Press. Sousa, D.A. (2011b). How the ELL brain learns. Thousand Oaks, CA: Corwin Press.

Sylwester, R. (1995). A celebration of neurons: An educator's guide to the human brain. Alexandria, VA: ASTD Press.

United States Office of Personnel Management. (2008). Best practice: Mentoring. Retrieved from http://www.opm.gov/hrd/lead/BestPractices-Mentoring.pdf 
Watson, M.K., Pelkey, J., Noyes, C., \& Rodgers, M.O. (2019) Using Kolb's Learning Cycle to Improve Student Sustainability Knowledge. Sustainability, 11, 4602. https://doi.org/10.3390/su11174602

White, E.G. (1903). Education. Nampa, ID: Pacific Press.

Wolfe, P. (2010). Brain matters: Translating research into practice $\left(2^{\text {nd }} \mathrm{ed}.\right)$. Alexandria, VA: ASTD Press.

Zull, J.E. (2002). The art of changing the brain. Sterling, VA: Stylus.

\section{АНОТАЦІЯ}

Мета дослідження. Модель викладання й вивчення 4MAT і чотирьохрівнева еволюційна модель Киркпатріка широко застосовуються в сучасній освіті. У статті автори роблять компаративний огляд літератури з метою уточнення інтеграції та єдності між ними, а також для окремих теоретичних розвідок, які дозволяють переосмислити широкий діапазон дизайну лінгвістичного навчання й оцінки результатів навчання. Автори стверджують, що між дизайном викладання і оцінкою ефективності навчання в світлі мовних конструкцій введення / виведення існує єдність, яка допомагає викладачам / тренерам лінгвістики використовувати холистичну й дієву схему на початку навчання студентів. Ця єдність, також відповідає принципу Дж. Киркпатріка і В. Кіркпатрік: «Кінець є початок».

Методики дослідження. Дослідження проводилося 3 використанням багатомірного шкалювання при обробці даних методу семантичного диреренціала, а також методу документального аналізу.

Результати. Комбінація теорії системної роботи мозку та теорії фрактальної інформачії на початковій стадії підтвердила, що модель викладання й навчання 4МАТ і чотирирівнева модель оцінки Киркпатріка об'єднуються і накладаються одна на одну з точки зору теоретичних засад, тобто єдність між теорією викладання і теорією оцінки ефективності навчання. Така інтеграція бере свій початок не тільки від внутрішньої єдності, що підтверджується компаративним оглядом літератури, а й отримує теоретичну підтримку в міждисциплінарних дослідженнях. До того ж, ия інтеграція тісно пов'язана з мовним конструкціями введення / виведення у психолінгвістичному / нейролінгвістичному розумінні.

Висновки. Первинне дослідження з використанням теорії системної роботи мозку та інших теорій для аналізу інтеграції між моделлю викладання і навчання 4MAT і чотирирівневої очіночної моделлю Киркпатріка засвідчує єдність обох моделей. Це дослідження підтвердило мету написання статmі модернізація методології психолінгвістичного дослідження. Очікується, що реалізація компонентів / етапів мовних конструкцій введення / виведення, які пропонуються авторами в статті, в майбутньому розширить застосування обох моделей у теоретичній і практичній лінгвістиці та інших відповідних галузях. Що стосується навчання, автори рекомендують поєднувати дві моделі для аналізу більшої кількості моделей навчання та / або моделей оцінки ефрективності навчання на предмет єдності, запиту очінки ефективності 
навчання у взаємодії з практикою, або навіть зв'язати інші дисципліни в рамках імплементації фрактальної теорії інформації. Можливою пропозицією для дослідників у галузі психолінгвістики $\epsilon$ розробка навчальних програм $i$ уроків на засадах уніфікованих моделей (рис. 1 i 2), запропонованих у цьому дослідженні, а також очінки ефективності навчання й успішності учнів. Іншим потенційним напрямком дослідження $\epsilon$ використання кожного квадранта уніфікованих моделей і аналіз відповідних компонентів у більш специфічних мовних конструкціях введення / виведення в різних видах мовленнєвої діяльності (аудіювання, читання, говоріння, письмо. Що стосується практики, особливо в психолінгвістиці та / або інших відповідних галузях знань, то ключ до одночасного застосування двох цільових моделей залежить від того, наскільки пропорційно регулювати відповідні квадранти / рівні, а також від цілісності між ними для одночасного досягнення "динамічної рівноваги» в моделі викладання і навчання 4МАТ $і$ «Кінець $\epsilon$ початок» в чотирирівневої моделі оцінки Киркпатріка.

Ключові слова: психолінгвістика, теорія мозку, викладання, очінка успішності, 4МАТ, Кіркпатрік, мовні конструкції, введення / виведення.

Лин Я-Вей \& Базалук Олег. Использование теории системной работы мозга для анализа единства между языковыми конструкциями ввода/вывода: обоснование улучшения методологии

\section{АННОТАЦИЯ}

Цель исследования. Модель преподавания и изучения 4МАТ и четырехуровневая эволюционная модель Киркпатрика широко применяются в современном образовании. В статье авторы делают компаративный обзор литературы с целью уточнения интеграции и единства между ними, а также для отдельных теоретических разведок, которые позволяют переосмыслить широкий диапазон дизайна лингвистического обучения и оценки результатов обучения. Авторы утверждают, что между дизайном преподавания и оценкой эффективности обучения в свете языковых конструкций ввода/ вывода существует единство, которое помогает преподавателям/тренерам лингвистики использовать холистичную и действенную схему на начальном этапе обучения студентов. Это единство также соответствует принципу Дж. Киркпатрика и В. Киркпатрик: "Конец есть начало».

Методики исследования. Исследование проводилось с использованием многомерного шкалирования при обработке данных метода семантического дифференциала, а также метода документального анализа.

Результаты. Комбинация теории системной работы мозга и теории фрактальной информации на начальной стадии обучения студентов подтвердила, что модель преподавания и обучения 4MAT и четырехуровневая модель оценки Киркпатрика объединяются и накладываются друг на друга с точки зрения теоретической основы, т.е. образуется единство между теорией преподавания и теорией оценки эффективности обучения. Такая 
Використання теорії системнӧ̈ роботи мозку для аналізу...

интеграция берет свое начало не только от внутреннего единства, которое подтверждается компаративным обзором литературы, но и получает теоретическую поддержку в междисциплинарных исследованиях. $K$ тому же эта интеграция тесно связана с языковыми конструкциями ввода/вывода в психолингвистическом/нейролингвистическом понимании.

Выводы. Первичное исследование с использованием теории системной работы мозга и других теорий для анализа интеграции между моделью преподавания и обучения 4MAT и четырехуровневой оченочной моделью Киркпатрика утверждает единство обеих моделей. Это исследование привело к достижению цели написания статьи - модернизация методологии психолингвистического исследования. Ожидается, что реализация компонентов/этапов языковых конструкций ввода/вывода, которые предлагаются авторами в статье, в будущем расширит и применение обеих моделей в теоретической и практической лингвистике и других соответствующих областях. Что касается обучения, авторы рекомендуют соединить две модели для анализа большего количества моделей обучения и/или моделей оченки эффрективности обучения на предмет единства, запроса оценки эфрективности обучения во взаимодействии с практикой, или даже связать другие дисциплины в рамках имплементации фрактальной теории информации. Возможным предложением для исследователей в области психолингвистики является разработка учебных программ и уроков на основе унифицированных моделей (рис. 1 и 2), предложенных в этом исследовании, и оценка эфрфективности обучения и успеваемости учащихся. Другим потенциальным направлением исследований является использование каждого квадранта унифицированных моделей и анализ соответствующих компонентов в более специфических языковых конструкциях ввода/вывода (в разных видах речевой деятельности аудирование, чтение, говорение, письмо). Что касается практики, особенно в психолингвистике и/или других соответствующих областей знаний, то ключ к одновременному применению двух целевых моделей зависит от того, насколько пропорционально регулировать соответствующие квадранты/ уровни, а также от целостности между ними для одновременного достижения "динамического равновесия" в модели преподавания и обучения 4МАТ и "Конеи есть начало» в четырехуровневой модели оценки Киркпатрика.

Ключевые слова: психолингвистика, теория мозга, преподавание, оценка успеваемости, 4МАТ, Киркпатрик, языковые конструкции, ввод/вывод. 